\title{
The image of training and development consultancy in South Africa
}

\author{
F.E. Botha and J.H. Owens \\ Graduate School of Business Administration, University of the Witwatersrand, Johannesburg
}

The objective of this research was to establish the current image of training and development consultancy in South Africa in relation to the ideal as perceived by their clients. In view of the critical shortage of high-level manpower it was considered important to establish whether this service sector is effectively assisting organizations in developing their management to the required skill levels. Based on a survey of the literature on previous image studies, the research methodology combined the measurement of image by using a structured questionnaire with unstructured, subjective comment to arrive at a conclusion. The Repertory Grid technique was used to generate constructs for the semantic differential scale used in the questionnaire. This questionnaire was administered to training/ personnel officials of a sample of manufacturing companies in the PWV area. The responses to the questionnaire were analysed by means of basic descriptive statistics, factor analysis and $t$ tests. Certain image dimensions were highlighted, and the results showed that numerous discrepancies existed between the image of training and development consultants and the perceived ideal. It was concluded that in order to effectively assist in alleviating the shortage of highlevel manpower, training and development consultants should strive towards improving their analysis of problems, the correct identification of training needs and the customization of the training programmes to match specific South African corporate and cultural needs.

S. Afr. J. Bus. Mgmt. 1985, 16: $161-170$

Die doelwit met hierdie navorsing was om die huidige beeld van konsultasie ten opsigte van opleiding en ontwikkeling in Suid-Afrika te bepaal in verhouding tot die ideale beeld soos deur hul kliënte gesien. In die lig van die kritiese tekort aan hoëvlak-mannekrag was dit belangrik geag om vas te stel tot watter mate hierdie dienssektor effektief daarin slaag om organisasies behulpsaam te wees in die ontwikkeling van bestuur tot die verlangde kundigheidsvlakke. Gebaseer op 'n literatuuroorsig van vorige beeldstudies, was die navorsings. metodiek wat gebruik is ten opsigte van beeldmeting, ' $n$ kom binasie van ' $n$ gestruktureerde vraelys met ongestruktureerde subjektiewe kommentaar om die nodige gevolgtrekkings te kon maak. Die 'Repertory Grid'-tegniek is gebruik om begrippe te genereer vir die semantiese differensiêleskaal wat in die vraelys gebruik is. Die vraelys is uitgestuur na opleidings-/personeelbeamptes wat ' $n$ verteenwoordigende monster is van vervaardigingsmaatskappye in die PWV-gebied. Die antwoorde op die vraelyste is ten opsigte van basiese beskrywende statistieke, faktoranalise en $t$-toetse ontleed. Sekere beelddimensies is beklemtoon en die resultate het aangedui dat verskeie verskille tussen die beeld van opleidings- en ontwikkelingskonsultante en die verlangde ideaal bestaan. Daar is afgelei dat om 'n effektiewe bydrae ten opsigte van die tekort aan hoesvlakmannekrag te maak, opleidings- en ontwikkelingskonsultante 'n poging moet aanwend om probleemanalise, die korrekte identifisering van opleidingsbehoeftes en die aanpasbaarheid en doelgerigtheid van opleidingsprogramme te verbeter, ten einde die spesifieke behoeftes van die Suid-Afrikaanse bedryfs- en kulturele identiteit te bevredig of daaraan te voldoen.

S.-Afr. Tydskr. Bedryfsl. 1985, 16: $161-170$

F.E. Botha and J.H. Owens*

Graduate School of Business Administration, University of the Witwatersrand, P.O. Box 31170, Braamfontein, 2017 Republic of South Africa

*To whom correspondence should be addressed

\section{Introduction and problem definition}

'Human resources - not capital, nor income, nor material resources - constitute the ultimate basis for the wealth of nations. Clearly a country which is unable to develop the skills and knowledge of its people and to utilize them effectively in the national economy will be unable to develop anything else'.

Harbison (1973)

South Africa is experiencing a critical shortage of skilled management, from supervisory and middle management to senior management level. This shortage of high-level human resources has been investigated and documented by many researchers and the urgency of the matter resulted in an initial investigation and report by the National Manpower Commission in 1980.

Sadie (1978) classified the labour force into four groups according to skill and employment status (excluding the agricultural sector) based on the Manpower Survey of the Department of Labour of 1975. Sadie found that the ratio of the executive group (socio-economic status or ability hierarchy) to the total labour force was 1:42, and pointed out that comparable ratios in other countries were 1:15 for Japan, 1:11 for Australia and 1:6 for the U.S.A. In a subsequent study based on the 1977 Manpower Survey, Sadie (1979) found that this ratio had changed to 1:52 for South Africa, with an equivalent ratio of $1: 15$ for developed countries and 1:10 for the U.S.A. The South African situation is represented by an inverted triangle with the pressure of the non-executive group increasing on the narrow base of the executive group.

This situation is complicated by the fact that the executive group has traditionally been drawn from members of the white population, and that the development of executive-level skills in other population groups has been hampered by inadequate standards of education, legislative restriction and rapid population growth. This has resulted inter alia in increased stress being placed on the white executive group.

Owing to the critical shortage of high-level manpower as described, and the consequent stresses being placed on existing management, the necessity has arisen for concerted efforts to train and develop sufficient human resources to the skill levels required to cope with the demands.

The government has recognized this urgent need for training and encouraged it by legislative measures such as the InService Training Act of 1979, and subsequently the Manpower Training Act of 1981. The Income Tax Act of 1962 (as amended) also provides for a tax deduction for training expenditure incurred for registered training courses held by registered training centres or schemes. 
A large number of training and development consultancies have been established in the past few years, resulting in a highly fragmented growth industry of individuals and organizations who market their services to companies either as true consultants or as 'purveyors of training packages'. In view of the high-level manpower shortage as described, it is important to establish whether training and development consultants are perceived to be effectively assisting South African companies in the development of these urgently needed resources. Such development implies not only an increase in the quantities of supervisors, middle and senior managers, but also the development of the qualitative skills required to manage the complexities with which South African companies are faced in the $80 \mathrm{~s}$.

\section{Objectives of the research}

The primary objective of this research was to establish the image of training and development consultancy in South Africa, i.e. the perceptions organizations have of training consultants with regard to their function, performance, competence, professionalism, ethical conduct, and their ability to identify and assist in satisfying organizational training needs.

A further objective was to establish the requirements of the ideal training consultancy, as perceived by the organizations that use consultants, thereby attempting to locate the current position of consultancy in this area in relation to the ideal.

A final objective was to establish whether any differences exist between companies of different size in the perceived and ideal image.

\section{Training and development consultancy}

Various researchers have given their views on how a consultative relationship can be defined (Lippitt \& Lippitt, 1978; Blake \& Mouton, 1976; Argyris, 1970) and have proposed various models to describe consultation (Schein, 1969; Kolb \& Frohman, 1970; Lippitt \& Lippitt, 1978).

Gallessich (1982) regarded consultation as being in the development phase of an emergent profession - a view which coincides with that of Lippitt (1981). The rise of consumerism has resulted in greater expectations regarding their services and technological changes and the media have added their demands to the pressures and tensions inherent in the relationship. In the light of these developments, consultants need to have certain skills and competencies in order to render satisfactory service. Lippitt (1981), in his article on selecting, evaluating and developing consultants, listed the qualities required in terms of a number of intellectual and personal attributes. These, in turn, become the criteria for assessing the competence of a consultant and include the following:

(a) The ability to form sound interpersonal relations with the client.

(b) Preventing or avoiding client dependency on the consultant's services.

(c) The ability to focus on the problem at hand.

(d) Being non-judgemental and tolerant towards other consultants and response disciplines.

(e) Maintaining the confidence of the clients.

(f) Being specific about financial arrangements.

(g) Achieving influence appropriately in the organization.

(h) Indicating the skills possessed relative to the problem at hand.

(i) Informing the client clearly as to the role that is to be played and the contribution that can be made.

(j) Expressing willingness to have the services provided evaluated.
The success of the consultation relationship not only depends on the competencies and skills of the consultant, but involves the cooperation of the client as well. In his research on management consultancy in South Africa, Matthews (1972) found certain attitudes of management to be critical to the success of the consultation. These included:

(i) Management should not regard the use of consultants as a gesture of defeat and should realize the importance of creating a climate of cooperation within the organiza. tion.

(ii) Management should have a clear idea of what to expect of consultants, accept the fact that consultants are human and therefore keep their expectations within realistic bounds.

(iii) The commitment of management was critical to the success of the consultation process.

Since the discovery that productivity can be improved by improving and satisfying employees' social and psychological needs, human resource consultants have been employed by management to assist in attempting to reconcile organizational and employee needs. Techniques based on various theories have been utilized, such as conflict management, management by objectives, job enlargement and job enrichment, team building, problem solving, decision making, leadership style, and group dynamics.

The role of the training and development consultant will vary according to the situation. Variables such as the needs of the organization, the consultant's own personal needs, power and achievement motives as well as profit orientation will affect this role. The consultant may provide a solution to a problem already identified by the client, assist in identifying alternative solutions, or examine client-proposed solutions. All of these approaches may expose him to the dangers of being regarded as a seller of solutions, or a reliever of symptoms while the real problem remains unresolved.

Mumford (1975) examined the client-centred approach to consulting as proposed by Argyris (1970), and pointed out that client-centred consultancy is concerned with assisting the client in recognizing the problem rather than selling solutions. He underlined the need for a certain group of skills in good training consultants, the most significant being listening skills, i.e. 'listening for the real problems of a client and listening for his definitions of his wants, rather than listening for a clue in his activities which gives the consultant an excuse to provide a solution which he happens to be good at' (Mumford, 1975: 131).

Various attempts have been made in countries throughout the world to arrive at competency models for training practitioners, including consultants. During 1983, the latest study in the U.S.A. produced 'Models for Excellence' under the study directorship of Patricia Mclagan for the American Society of Training and Development.

In South Africa there has been an increasing trend towards specialization among training and development consultancies. Consultants have also been able to implement change programmes faster, and an increased distribution of training programmes has become evident, together with a decreasing dependency on the consultant for implementation. One can conclude from these trends that there has been a shift in emphasis from the diagnostic and prescriptive role of training consultancy towards a process consultation relationship (defined by Schein (1969:9) as 'a set of activities on the part of the consultant which help the client to perceive, understand and act on process events which occur in the client's environment') in organizations that are termed more 'aware' (West- 
cott, 1984, personal communication; Spamer, 1984, personal communication).

Three factors are seen to have been responsible for the greater awareness of the importance of training. Firstly, the critical skilled manpower shortage has emphasized the need for training. Secondly, legislative changes encouraging training have resulted in a large amount of publicity and awareness of training, and a consequent increase in demand for the services of training consultancies. Thirdly, multinational companies operating in South Africa have had a positive influence on local companies as a result of their need to comply with the various codes of business practice. These usually include a heavy emphasis on training and development.

In some cases training and development consultancy originally developed as an offshoot of management consultancy, whereby training became a necessary part of implementing a change system in a company as a consequence of a consulting assignment (Westcott, 1984, personal communication). Subsequently several training and development consultancies developed in response to the greater need for specialization, either as separate divisions within broader management consultancies or personnel consultancies, or as specialist training consultancies.

\section{Research methodology}

\section{Previous image research}

The concept of image and imagery is used extensively in strategic marketing, advertising and market research. The architect of the 'Image' era in advertising is said to have been David Ogilvy who successfully proved the validity of his ideas in campaigns like those for Rolls-Royce and Schweppes. Although 'positioning' has succeeded 'image' as the marketing strategy of the 80 s (Ries \& Traut, 1981), image is still a concept of great concern to companies regarding their corporate image, products and stores. Little academic research on image was found to have been undertaken in South Africa. Two researchers (Polovin, 1975 and Braude, 1975) utilized the Repertory Grid technique to generate constructs which could be used in the design of a questionnaire for the measurement of image. This technique is discussed in greater detail below.

Schein \& Hall (1967) examined the image of teachers as held by their students. Descriptive attributes classified into three groups were elicited from the students. On analysis, three clusters of dimensions were revealed:

(i) Intellectual and communicative competence

(ii) Personal potency

(iii) Commitment to the role of teacher.

These corresponded to three basic dimensions of

- competence,

- potency, and

- supportiveness.

Each teacher was scored on the descriptive attributes and profiles were obtained based on the three dimensions.

It was found that teachers who scored highly in competence, were found among the 'good'-teachers set, teachers who scored highly in potency were found equally in the 'good' and 'bad'-teachers sets. Those who scored highly on supportiveness were more often found in the 'poor' set.

Congruence was found between the dimensions isolated and those described by McClelland's theory of motivation which identifies three basic needs, i.e. need for achievement (competence), need for power (potency), and need for affiliation (supportiveness), as well as other research in leadership theories. This tends to indicate that these three dimensions reflect the key style components of any authority role.

Cogill (1981) found that the perception of the personnel manager was found to be lacking clear direction and purpose and that he was incapable of exercising influence over the attitudes and behaviour of other individuals or groups. $\mathrm{He}$ was not seen to have power by controlling money, information or knowledge that was valued by others.

These findings are of relevance and importance to this research from the point of view of the attributes perceived. As many training and development consultants are drawn from the ranks of personnel practitioners it may be interesting to examine whether these conclusions apply to the image of consultants.

\section{Research in the training and development field}

Hendricks (1981) found that $95 \%$ of the respondents in his research on the training needs of trainers and available training felt that adequately trained training personnel were not readily available.

The cost of not having training personnel adequately trained before they enter the industry was estimated as at least 300 million rand per annum, based on conservative costs of extra training courses over a five-year period, and $1 \%$ improvement in added value per employee lost over the five years.

Gabler (1982) concluded from his research that the tax rebate system was not an adequate incentive to encourage small companies to undertake training, as cash flow and loss of man-hours outweighed the benefits of the tax concessions. He concluded further that the private sector and large companies in particular, are doing very little to alleviate the skilled manpower shortage' (Gabler, 1982:194).

\section{Methodology}

Research is conducted in terms of the frame of reference of the researcher, which determines the nature of the research and the methodology used (Gerdes, 1981). The mechanistic approach to research accentuates quantitative data and total objectivity in observation and measurement; the organic or holistic approach includes subjective methods of collection and interpretation. This 'objectively subjective' approach to research, has been seen in various fields such as phenomenology, ethnomethodology and participant observation in the behavioural sciences, and has also been used in this research.

Man is constantly being bombarded with messages or stimuli from his environment. Ries \& Traut (1981) maintained that we have become an overinformed society, and the only defence a person has to our overinformed society is an oversimplified mind. In order to create some form of simplified order with which he can cope with this mass of information, a person organizes it into images. According to these images, a person will respond or react.

In order to assess the dimensions of image, the elemental attributes towards which attitudes are held, need to be isolated. Each of these attitude elements is called a construct, which is basically a concept invented or adopted for a specific purpose. A construct is defined as having dimensionality and is therefore a continuous variable. It is observable and measurable and related to other constructs. The technique used to elicit the constructs is based on Kelly's personal construct theory and the Repertory Grid Technique.

Based on his personal construct theory, Kelly devised the Repertory Grid as a technique whereby mathematical relationships between constructs could be obtained and therefore social behaviour could be construed in a multidimensional way. Based on the bipolarity of constructs, the design of grids becomes possible and people can reveal in mathematical terms 
a coherent picture of how they construe their world.

The Repertory Grid technique has proved to be a highly flexible test, and is a method whereby respondents can provide their own constructs, thereby defining their perceptions of the reality which has meaning for them. In this way the attributes which make up a person's image of something or someone can be elicited.

The constructs generated using the Repertory Grid technique eliminate researcher subjectivity to a large extent, and are accurate, reliable and valid. In order to measure the image formed, the attitudes elicited must be measured on a scale.

The semantic differential has been employed successfully by researchers for various applications, including the determination of image, as it provides a method whereby the constructs generated by Kelly's Repertory Grid can be quantified and image can be measured with reasonable reliability.

- Primary data were collected from respondents via a structured questionnaire which used the semantic differential to measure the attributes of the images of the training and development consultants. Constructs were elicited for the design of the questionnaire, and the questionnaire was administered to human resource managers/training managers of the sample selected.

- Secondary data:

(i) Desk research - a survey of the literature was conducted to provide a theoretical basis for the research methodology. A survey of prior research relevant to the areas covered was also conducted. Journal articles, books and official reports of the Department of Manpower, provided further background information to the areas covered.

(ii) Interviews - during the interviews for the generation of constructs, unstructured discussions took place with the training officials of the companies interviewed.

- Interviews were held with officials of the S.A.S.T.D. to provide background material.

- Interviews were also held with officials of the Department of Manpower for this purpose.

- Interviews were also conducted with training consultants, to provide a background to training consultancy in South Africa.

(iii) Unstructured comment - as a consequence of Polkinghorne's (1976) findings it was decided to attach a blank page to the structured questionnaire on which respondents could express attitudes on training and development consultants not covered in the questionnaire constructs. These responses were used, together with other unstructured comments made during the Repertory Grid interviews as an adjunct to draw conclusions and make recommendations.

Against the theoretical background given, the following is a description of the methods used to assess the image of training and development consultants.

\section{Sample selection}

The population was defined as companies with more than 500 employees that used the services of external training and development consultants. Within this population, a target set within the PWV area was selected. A sampling frame of manufacturing companies was chosen for the purposes of the study; the rationale being that manufacturing companies employing more than 500 people were judged to be most likely to use the services of training and development consultants. The sample frame also represented a substantial percentage of manufacturing companies in South Africa, and would be easy to contact and follow-up.

A list of manufacturing companies in the PWV area employing more than 500 people was obtained from the Bureau for Market Research, which supplied names and addresses of the companies, coded by population group and industrial activity type. This list contained the names of 333 companies.

As previous research by Gabler (1982) had shown that larger companies were more likely to spend money on training, it was assumed that they were more likely to use the services of external training and development consultants. For this reason it was decided to stratify the list into three employment groups as follows:

Group A: more than 1500 employees $(n=59)$

Group B: $800-1500 \quad$ employees $(n=103)$

Group C: $500-800 \quad$ employees $(n=171)$

The following disproportionately stratified sample was taken, giving a sample size of 60 :

$25 \%$ of Group $A=15$

$20 \%$ of Group B $=20$

$15 \%$ of Group $C=25$

Total $=60$

In order to arrive at each element of the sample, a systematic sampling procedure was undertaken in each group, which implied that every fourth company in Group A, every fifth company in Group B and every seventh company in Group C was selected. A random start was made in each group to ensure an unbiased sample. This resulted in the selection of the second company in Group A, the fourth company in Group B and the third company in Group C.

The following problems were encountered in attempting to contact the companies to establish whether their training functions were located in the PWV area and whether management/supervisory training was undertaken with the use of external consultants, and thereby confirm that the company could be included in the sample:

(i) The company could not be contacted telephonically, i.e. it was not listed in the $1983 / 1984$ directory or could not be traced via directory information services.

(ii) The company had a registered office in the PWV area, but its headquarters, manufacturing and training functions were located outside the geographic area selected for the study.

(iii) The company did not undertake supervisory/management training.

(iv) The training officer/personnel manager did not know consultants well enough to express an opinion, or did not use the services of external consultants for supervisory/ management training.

(v) Supervisory/management training was done by a sister or parent company.

(vi) There was a certain amount of duplication in the list, e.g. Nampak Corregated Products and Nampak Products Limited, both with the same address.

The above problems necessitated a lengthy iterative procedure before a final list of 60 elements was arrived at, which fulfilled the statistical requirement that each was selected with the same probability.

The number of iterations necessary in each group were: Group $A=6 \quad(10,2 \%)$

Group B $=29 \quad(28,2 \%)$

Group $C=56 \quad(32,7 \%) \quad($ mean $=23,7 \%)$

Although this proved to be a lengthy procedure, personal contact with training officers/personnel managers was judged to be more effective in ensuring a better response rate. 
If one assumes that $23,7 \%$ of the list of 333 companies do not qualify for inclusion in the sample frame this sample frame is reduced to 253 . The sample size of 60 represents $24 \%$ of this figure, which can be regarded as a significant sample for the purposes of drawing valid conclusions from the results of the study.

For the purposes of comparing the images of consultancies in companies of different size the sample was divided into two employment groups:

Group 1: more than 1000 employees $(n=26)$.

Group 2: 500 - 1000 employees $(n=34)$.

\section{Construct generation}

The Repertory Grid Procedure was used for this purpose. In order to generate the constructs for questionnaire design, a sample of the target population was chosen. Twenty companies were chosen for this purpose. Previous researchers had found that $23-25$ interviews were necessary to make an exhaustive list of constructs. As this research is a pilot study, an exhaustive list was not required. Twenty interviews were therefore judged to be sufficient.

The identity of the training managers/officers of the companies was established and appointments were made with each of them for an interview, after the purpose of the research was explained. During the interview, 20 cards with the names of training and development consultants, numbered in alphabetical order, were presented to the interviewee who was asked to eliminate those whom he/she did not have sufficient knowledge or experience of to allocate attributes to. (The list of consultants used in this exercise was obtained from the list generated by Trump (1983)).

Using the remaining cards, respondents were then asked to rank the training and development consultants in order of choice. The above two procedures were done in order to arrive at a 'short list' of the most well known and frequently used consultancies for use in the final questionnaire.

The Triad Procedure for eliciting constructs as described by Kelly was employed. Three cards were placed in front of respondents who were asked to state in which way two of the consultancies were similar and different from the third. The words or expressions used were then noted. When no more constructs could be elicited voluntarily from the Triad, prompts were used. The Triad was then changed by eliminating one card and replacing it with another. This procedure was continued until all constructs from all possible combinations had been elicited.

A short, unstructured discussion followed the Repertory Grid Procedure, during which other opinions and impressions of interest were noted. Interviews lasted from 45 to 105 minutes, with a mean of 58,25 minutes, and interviewees varied in their ability to generate constructs, with a minimum of 18 and a maximum of 89 constructs being generated in one interview.

The rationale for using the Repertory Grid Technique, is that researcher subjectivity is eliminated, as constructs are elicited from training practitioners themselves, and therefore other respondents would be most likely to identify with the attributes given in the questionnaire. This attempts to approach the communality and experience corollaries of Kelly's basic postulate (Bannister \& Fransella, 1980:24-27).

\section{Questionnaire design}

The constructs generated in the above procedure were examined for duplication of meaning and those with the same meaning were grouped together. On examination it was found that four groups of constructs could be identified, under the following headings:

- General image

- Marketing style

- Characteristics of training courses

- Characteristics of individual consultants

As the limitations of the study dictated that the complete list of constructs could not be used, a frequency count was made to establish 30 constructs most frequently used for use in the final questionnaire. The constructs were either in the form of a word or a descriptive phrase. The use of a descriptive phrase is justified from the point of view of the possibility of ambiguity.

The 30 constructs were then arranged in a random order, with favourable/unfavourable attributes randomly distributed between left and right-hand poles of the seven-point scale. The reason for the random dispersion, rather than presentation under the four headings described, was to reduce any possible 'halo' and/or 'anchoring' effect which could occur as a result of attributes belonging to the same group being positioned in successive order.

Eight training and development consultants who were most frequently used and most well known were also arrived at by the frequency count procedure. The two classifications corresponded exactly. These consultancies together with the ideal were listed, each with a code letter. Respondents were asked to rate the consultancies they knew, as well as their ideal consultancy by placing the code letter in a position on the scale which best fitted the description of the consultancy. A blank page was also attached to allow respondents to express any additional attitudes or opinions not covered by the attributes in the structured questionnaire, consultancies not listed, or any other relevant topic.

\section{Analysing the data}

As the nature of the research is basically exploratory the techniques for analysing the data initially involved basic descriptive statistics. As perceptions differ widely, the responses to the semantic differential need not necessarily follow a normal distribution. This precludes the application of extensive inferential statistics to the data. However, the $t$ test which is applied to the means obtained has been found to be a very robust test and can be used where the sample departs from normality (Polkinghorne, 1976:140).

The following techniques were used to provide the image dimensions and attribute profiles of training and development consultancies as well as those of the ideal consultancy: basic descriptive statistics, multivariate analysis, and $t$ tests between means. Differences between the actual and the ideal can be estimated and in this way the primary objective of the research can be achieved. The particular attributes which relate to the marketing aspects of the services of training and development consultancies could be isolated and the relevant profiles and dimensions determined for these attributes. Once again the differences can be estimated. This satisfies the second objective of the research, namely to show that training and development consultancy suffers from a lack of a true marketing orientation. As the questionnaires were coded according to company size the two groups to be compared could be isolated and the relevant dimensions and profiles for each employment group established. In this way the third objective of the research could be achieved, namely that no differences in perception exist between companies of different size.

The seven-point semantic differential scale was scored by allocating a number from one to seven to each space. The 
positions of the code letters for each consultancy were recorded according to the number of that particular space. Matrices obtained from the questionnaires varied from $2 \times$ $7 \times 25$ to $9 \times 7 \times 30$, according to the number of consultancies and attributes scored.

Data processing was carried out using the CMS/SAS statistical package. The raw scores for each questionnaire were entered into a SAS data set with the code for each questionnaire. The initial analysis consisted of descriptive statistics to validate the data. Subsequently the factor procedure was used to perform factor and component analysis, as it is desirable to describe the relationship in terms of one component or factor instead of many. Orthogonal and oblique rotations were executed. The output of the procedure provided the following:

(i) Means

(ii) Standard deviations

(iii) Correlations

(iv) Screen plots of eigenvalues

(v) Factor patterns

(vi) Rotated factor patterns

(vii) Tests for validity of factors, data, etc. (e.g. Kaiser's measure of sampling adequacy).

Using the means obtained, profile graphs could be plotted.

\section{Evaluation of the results}

\section{Response to the questionnaire}

Fifty-two of the 60 questionnaires posted were returned, representing an overall response rate of $86,7 \%$ which was at least $20 \%$ of the sampling frame. This was considered adequate for a personally administered questionnaire. An analysis of the response rate in the three strata of the sample shows the following:

\begin{tabular}{lccc}
\hline Stratum & $\begin{array}{c}\text { Number } \\
\text { posted }\end{array}$ & $\begin{array}{c}\text { Number } \\
\text { returned }\end{array}$ & $\begin{array}{c}\text { Response } \\
\text { rate }\end{array}$ \\
\hline more than 1500 employees & 15 & 10 & $67 \%$ \\
$800-1500$ employees & 20 & 18 & $90 \%$ \\
$500-800$ employees & 25 & 24 & $96 \%$ \\
\hline
\end{tabular}

The response rate for the larger companies was disappointing. Of the total non-response rate of $13,3 \%, 8,3 \%$ were from this group. However, the response represented at least $20 \%$ of the sample frame in that stratum.

The two employment groups to be compared showed the following response rates which were considered adequate:

\begin{tabular}{lccc}
\hline Employment group & $\begin{array}{c}\text { Number } \\
\text { posted }\end{array}$ & $\begin{array}{c}\text { Number } \\
\text { returned }\end{array}$ & $\begin{array}{c}\text { Response } \\
\text { rate }\end{array}$ \\
\hline S00-1000 employees & 34 & 32 & $94 \%$ \\
more than 1000 employees & 26 & 20 & $77 \%$ \\
\hline
\end{tabular}

Of the 52 questionnaires returned, 35 had subjective comments on the blank page provided; some brief but others more extensive. This showed that respondents generally welcomed the opportunity of expressing subjective comments on areas not covered by the questionnaire.

\section{Analysis of results}

In order to test whether the hypotheses are proved or not, the null hypothesis and an alternative hypothesis are set up in each case.

$\mathbf{H}_{\mathbf{0}}: \mathbf{M}_{\mathbf{I}}=\mathbf{M}_{\mathbf{A}}$ or $\mathrm{H}_{0}:+\mathbf{M}_{\mathbf{I}}-\mathbf{M}_{\mathbf{A}}=\mathbf{0}$
$H_{1}: M_{1} \neq M_{A}$ or $\mathrm{H}_{1}: \mathrm{M}_{\mathbf{l}}-\mathrm{M}_{\mathrm{A}} \neq 0$ where $\mathrm{H}_{0}=$ null hypothesis; $\mathrm{H}_{\mathrm{l}}=$ alternative hypothesis; $\mathbf{M}_{\mathbf{I}}=$ mean of ideal consultancy; and $\mathbf{M}_{\mathrm{A}}=$ mean of all consultancies.

A $t$ test is performed at the $95 \%$ confidence level to establish whether $\mathrm{H}_{0}$ can be accepted or not. If it is sufficiently large, the null hypothesis is rejected and the alternative hypothesis accepted.

\section{Differences between the ideal consultancy and all other consultancies}

The primary hypothesis to be tested in this instance is that the means of the ideal consultancy and all other consultancies will differ. This implies that the null hypothesis will be rejected.

The following results were obtained:

(i) Means for the ideal consultancy.

(ii) Means for all other consultancies together.

(iii) Means for each individual consultancy.

(iv) $t$ tests between (i) and (ii) at the $95 \%$ confidence level.

(v) $t$ tests between (i) and each of (iii) at the $95 \%$ confidence level.

The profile graph for the mean of all consultancies compared to the ideal is shown in Figure 1.

The results indicate that at the $95 \%$ confidence level, the $t$ test showed that significant differences occurred between the means of 25 out of 30 variables when all consultancies were compared to the ideal. Fifteen of the 30 variables were located either between 1 and 2 or between 6 and 7 , showing that

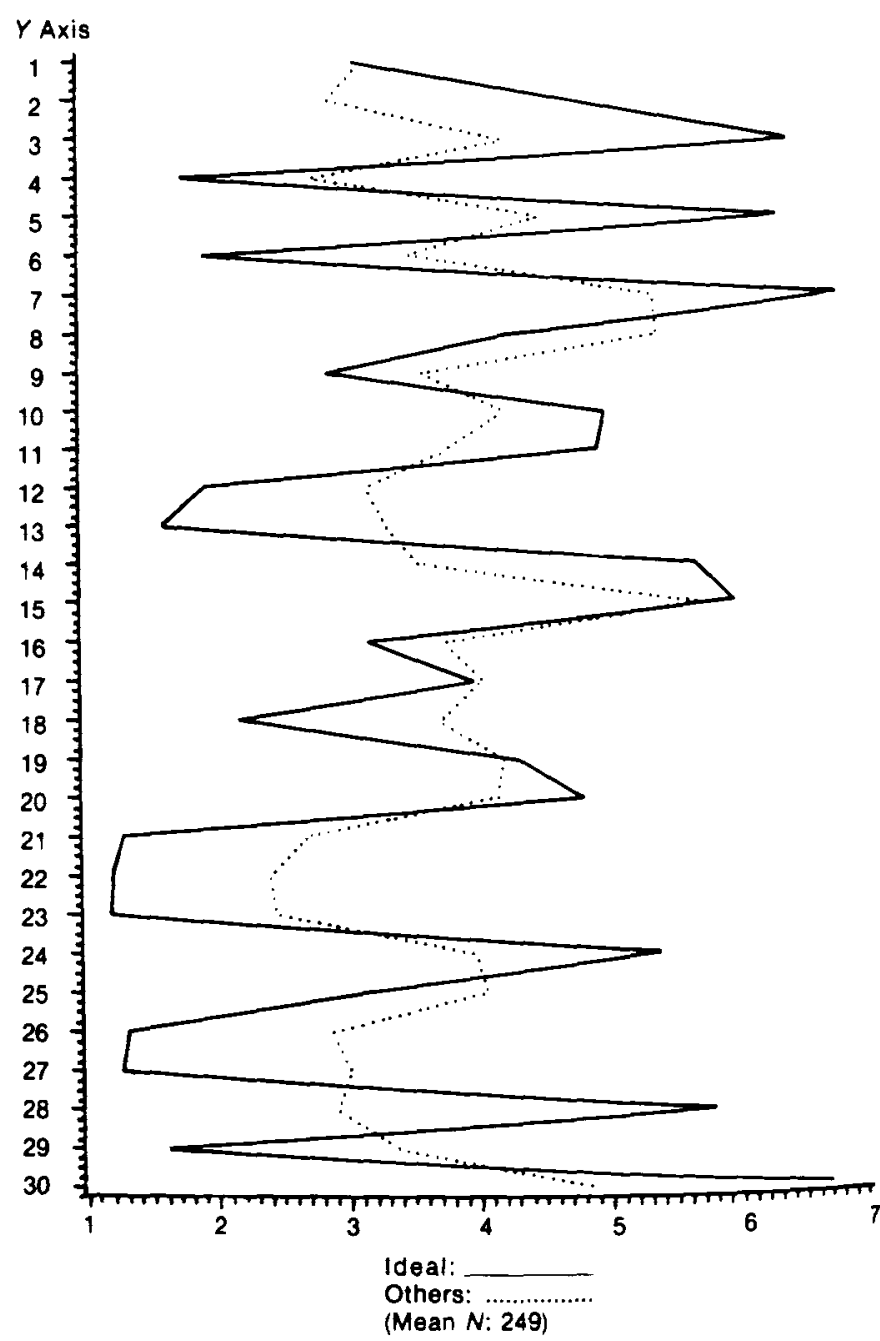

Figure 1 Profile graph of mean of all consultancies against mean of ideal. 
Table 1 Differences between ideal and consultancies

\begin{tabular}{|c|c|c|c|c|c|c|c|c|c|c|}
\hline Variable & $\begin{array}{l}\text { Mean } \\
\text { ideal }\end{array}$ & $\begin{array}{c}\text { Mean } \\
\text { All/I }\end{array}$ & $\begin{array}{c}\text { Mean } \\
\text { A/I }\end{array}$ & $\begin{array}{c}\text { Mean } \\
\text { B/I }\end{array}$ & $\begin{array}{c}\text { Mean } \\
\text { C/I }\end{array}$ & $\begin{array}{c}\text { Mean } \\
\text { D/I }\end{array}$ & $\begin{array}{c}\text { Mean } \\
\text { E/I }\end{array}$ & $\begin{array}{c}\text { Mean } \\
\text { F/I } \\
\end{array}$ & $\begin{array}{c}\text { Mean } \\
\text { G/I }\end{array}$ & $\begin{array}{c}\text { Mean } \\
\mathrm{H} / \mathrm{I}\end{array}$ \\
\hline 1 & 3,0 & 3,12 & 3,44 & 2,95 & 3,35 & $3,76^{a}$ & 2,49 & $2,07^{a}$ & 3,59 & $4,36^{a}$ \\
\hline 2 & 4,6 & $2,86^{\mathrm{a}}$ & $3,00^{\mathrm{a}}$ & $2,37^{a}$ & $2,34^{a}$ & $2,42^{\mathrm{a}}$ & 5,35 & $2,43^{a}$ & $2,15^{a}$ & $2,33^{\mathrm{a}}$ \\
\hline B 3 & 6,4 & $4,19^{a}$ & $4,25^{\mathrm{a}}$ & $4,13^{a}$ & $4,19^{2}$ & $4,55^{a}$ & 4,29 & $3,69^{a}$ & $4,54^{2}$ & $4,11^{\mathrm{a}}$ \\
\hline B 4 & 1,7 & $2,72^{\mathrm{a}}$ & $2,53^{a}$ & $2,58^{\mathrm{a}}$ & 2,36 & $3,60^{a}$ & $2,72^{a}$ & 2,16 & $3,03^{2}$ & $3,72^{\mathrm{a}}$ \\
\hline B 5 & 6,3 & $4,47^{a}$ & $4,29^{2}$ & $4,72^{\mathrm{a}}$ & $4,34^{2}$ & $4,39^{a}$ & $4,88^{a}$ & $4,34^{a}$ & $2,29^{\mathrm{a}}$ & $4,46^{\mathrm{a}}$ \\
\hline B 6 & 1,8 & $3,47^{\mathrm{a}}$ & $3,34^{a}$ & $4,39^{a}$ & $4,18^{\mathrm{a}}$ & $3,48^{a}$ & $3,23^{\mathrm{a}}$ & $3,28^{\mathrm{a}}$ & $3,15^{\mathrm{a}}$ & $3,94^{\mathrm{a}}$ \\
\hline B 7 & 6,8 & $5,34^{\mathrm{a}}$ & $5,25^{\mathrm{a}}$ & $5,33^{\mathrm{a}}$ & $5,41^{\mathrm{a}}$ & $5,09^{a}$ & $5,41^{a}$ & $5,66^{\mathrm{a}}$ & $5,32^{a}$ & $4,83^{a}$ \\
\hline 8 & 4,2 & $5,36^{a}$ & $5,23^{\mathrm{a}}$ & $5,49^{\mathrm{a}}$ & $5,64^{a}$ & $5,28^{a}$ & 3,87 & $6,07^{\mathrm{a}}$ & $5,87^{\mathrm{a}}$ & $5,58^{\mathrm{a}}$ \\
\hline 9 & 2,8 & $3,56^{\mathrm{a}}$ & 3,39 & 3,17 & $5,21^{\mathrm{a}}$ & $3,96^{\mathrm{a}}$ & 3,19 & $2,00^{\mathrm{a}}$ & $4,53^{\circ}$ & $4,00^{\mathrm{a}}$ \\
\hline 10 & 4,9 & $4,19^{a}$ & 4,15 & 4,24 & 4,41 & $3,90^{\mathrm{a}}$ & 4,10 & $3,87^{a}$ & 4,67 & 4,31 \\
\hline 11 & 4,9 & $3,77^{\mathrm{a}}$ & $3,87^{\mathrm{a}}$ & 5,06 & $1,68^{\mathrm{a}}$ & $2,78^{a}$ & $6,61^{a}$ & $4,32^{\mathrm{a}}$ & $2,29^{a}$ & $2,05^{a}$ \\
\hline B12 & 1,9 & $3,14^{\mathrm{a}}$ & $3,16^{\mathrm{a}}$ & $2,92^{\mathrm{a}}$ & $2,61^{\mathrm{a}}$ & $4,13^{a}$ & $3,09^{a}$ & $3,35^{\mathrm{a}}$ & $2,79^{a}$ & $3,42^{a}$ \\
\hline B13 & 1,5 & $2,29^{\mathrm{a}}$ & $3,42^{\mathrm{a}}$ & $2,71^{\mathrm{a}}$ & $4,26^{\mathrm{a}}$ & $3,33^{a}$ & 1,81 & $2,93^{\mathrm{a}}$ & $4,31^{a}$ & $4,68^{a}$ \\
\hline 14 & 5,6 & $3,53^{\mathrm{a}}$ & $3,24^{\mathrm{a}}$ & $4,11^{a}$ & $3,06^{\mathrm{a}}$ & $3,16^{\mathrm{a}}$ & $4,70^{\mathrm{a}}$ & $3,26^{\mathrm{a}}$ & $3,00^{2}$ & $3,33^{\mathrm{a}}$ \\
\hline B15 & 5,9 & 5,66 & 5,56 & 6,00 & 6,37 & $4,78^{a}$ & 5,57 & 6,24 & 5,50 & $3,38^{\mathrm{a}}$ \\
\hline 16 & 3,1 & 3,74 & 3,41 & 3,66 & 3,66 & $4,23^{\mathrm{a}}$ & 3,05 & 3,66 & $4,62^{\mathrm{a}}$ & $4,05^{a}$ \\
\hline 17 & 3,9 & 4,03 & 3,76 & 4,56 & $4,77^{\mathrm{a}}$ & 3,90 & 4,34 & 3,97 & $2,85^{\mathrm{a}}$ & 3,47 \\
\hline 18 & 2,1 & $3,69^{\mathrm{a}}$ & $3,52^{\mathrm{a}}$ & $3,47^{a}$ & $4,84^{\mathrm{a}}$ & $3,76^{\mathrm{a}}$ & $3,75^{\mathrm{a}}$ & $3,51^{\mathrm{a}}$ & $3,17^{\mathrm{a}}$ & $3,24^{\mathrm{a}}$ \\
\hline 19 & 4,3 & 4,18 & 4,33 & $2,72^{\mathrm{a}}$ & $5,55^{\mathrm{a}}$ & 5,10 & $3,21^{\mathrm{a}}$ & $3,23^{\mathrm{a}}$ & $5,92^{\mathrm{a}}$ & 4,82 \\
\hline 20 & 4,8 & 4,13 & 4,06 & 4,24 & 3,84 & $3,95^{\mathrm{a}}$ & 4,11 & $3,95^{\mathrm{a}}$ & 5,11 & $3,71^{\mathrm{a}}$ \\
\hline B21 & 1,2 & $2,70^{a}$ & $2,50^{\mathrm{a}}$ & $2,51^{\mathrm{a}}$ & $2,84^{\mathrm{a}}$ & $2,83^{\mathrm{a}}$ & $3,06^{2}$ & $2,56^{\mathrm{a}}$ & $2,89^{a}$ & $3,00^{\mathrm{a}}$ \\
\hline B22 & 1,1 & $2,39^{\mathrm{a}}$ & $2,34^{\mathrm{a}}$ & $2,25^{\mathrm{a}}$ & $2,09^{\mathrm{a}}$ & $2,87^{a}$ & $2,55^{\mathrm{a}}$ & $2,09^{a}$ & $2,48^{a}$ & $2,95^{a}$ \\
\hline B23 & 1,1 & $2,45^{a}$ & $2,34^{a}$ & $2,28^{\mathrm{a}}$ & $2,44^{\mathrm{a}}$ & $2,75^{\mathrm{a}}$ & $2,89^{\mathrm{a}}$ & $2,09^{a}$ & $2,23^{\mathrm{a}}$ & $2,85^{a}$ \\
\hline 24 & 5,3 & $3,95^{\mathrm{a}}$ & $4,57^{\mathrm{a}}$ & $3,41^{\mathrm{a}}$ & $4,06^{\mathrm{a}}$ & $3,29^{a}$ & $4,26^{\mathrm{a}}$ & $3,21^{\mathrm{a}}$ & 4,88 & $4,22^{\mathrm{a}}$ \\
\hline 25 & 3,1 & $4,05^{a}$ & $4,19^{\mathrm{a}}$ & $4,33^{\mathrm{a}}$ & $4,79^{\mathrm{a}}$ & 3,48 & 3,76 & $4,95^{\mathrm{a}}$ & 2,79 & 3,24 \\
\hline B26 & 1,3 & $2,85^{\mathrm{a}}$ & $2,66^{\mathrm{a}}$ & $2,55^{\mathrm{a}}$ & $3,72^{\mathrm{a}}$ & $3,35^{\mathrm{a}}$ & $2,39^{\mathrm{a}}$ & $2,70^{\mathrm{a}}$ & $2,70^{\mathrm{a}}$ & $3,10^{\mathrm{a}}$ \\
\hline B27 & 1,2 & $3,00^{\mathrm{a}}$ & $2,94^{\mathrm{a}}$ & $2,69^{\mathrm{a}}$ & $3,81^{\mathrm{a}}$ & $3,26^{\mathrm{a}}$ & $2,74^{\mathrm{a}}$ & $2,55^{\mathrm{a}}$ & $3,04^{a}$ & $3,60^{\mathrm{a}}$ \\
\hline 28 & 5,8 & $2,90^{\mathrm{a}}$ & $2,97^{\mathrm{a}}$ & $3,28^{\mathrm{a}}$ & $2,27^{\mathrm{a}}$ & $2,92^{\mathrm{a}}$ & $3,83^{a}$ & $2,50^{\mathrm{a}}$ & $2,22^{\mathrm{a}}$ & $3,06^{\mathrm{a}}$ \\
\hline B29 & 1,5 & $3,36^{\mathrm{a}}$ & $2,97^{\mathrm{a}}$ & $2,74^{\mathrm{a}}$ & $3,24^{a}$ & $3,92^{\mathrm{a}}$ & $2,83^{\mathrm{a}}$ & $3,07^{\mathrm{a}}$ & $4,68^{\mathrm{a}}$ & $4,29^{\mathrm{a}}$ \\
\hline B30 & 6,6 & $4,86^{\mathrm{a}}$ & $4,84^{\mathrm{a}}$ & $5,08^{a}$ & $4,37^{\mathrm{a}}$ & $4,88^{a}$ & $4,73^{a}$ & $4,93^{\mathrm{a}}$ & $5,29^{\mathrm{a}}$ & $4,75^{\mathrm{a}}$ \\
\hline
\end{tabular}

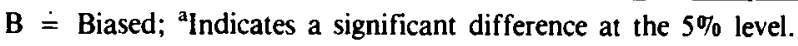

respondents could have exhibited excess bias towards their perceptions of the ideal consultancy in these instances. However, on three of these one of the consultancies had a mean value which was not significantly different from the ideal at the $95 \%$ confidence level. The number of variables on which excess bias could have been shown is therefore reduced to 12 . The results are summarized in Table 1 and the variables on which excess bias could have been exhibited are highlighted. (The names of the consulting companies included in this study have been withheld to protect their confidence. Instead, they are designated by initials such as A, B, C, D . . etc.)

An analysis of the number of significant differences between the means for the ideal consultancy and the means for each individual consultancy are shown in Table 2.

Table 2 Number of significant differences for each consultancy

\begin{tabular}{ccc}
\hline Consultancy & $\begin{array}{c}\text { Number of } \\
\text { N.S.D. }\end{array}$ & Number of S.D. \\
\hline A & 8 & 22 \\
B & 8 & 22 \\
C & 6 & 24 \\
D & 3 & 27 \\
E & 12 & 18 \\
F & 4 & 26 \\
G & 6 & 24 \\
H & 4 & 26 \\
\hline
\end{tabular}

N.S.D. = no significant difference,

S.D. = significant difference
It would appear from these results that consultancy $E$ comes closest to the perceived ideal consultancy, with consultancy A and B jointly in the second closest position. The results for consultancy $\mathrm{D}$ and $\mathrm{H}$ should be viewed with caution because of the low average response rates, $23,4 \%$ and $19,3 \%$ respectively. An examination of the profile graphs highlights the relative strengths and weaknesses of each consultancy as perceived by this sample of organizations. The specific image attributes can easily be identified and consultancies could benefit from analysing these to identify in which respects their services deviate from the ideal, and where they can be improved.

\section{Factor analysis}

Principle component analysis

This produced eight underlying components of the $\mathbf{3 0}$ variables, namely:

- Professional competence

- Service

- Potency

- Variety

- Activity

- Stability

- Size

- An ambiguous group

\section{Rotation of factors}

Both orthogonal (Varimax) and oblique rotations were performed on the principle components which produced four sets of more clearly defined factors and five unrelated 
variables. The factors isolated by the Varimax rotation are given in Table 3. The factor loadings as well as the consultancy which came closest to the ideal consultancy are indicated. Whether the difference was significant or not is also noted.

It is interesting to note that on rotation the three categories of attitudes, namely competence, potency and supportiveness, are elicited. Schein \& Hall (1967) found that teachers who were perceived as 'good' scored highly on the competency category of attributes. It is evident from the above findings that significant differences exist in six of the eight competency variables between the ideal consultancy and the consultancy that was perceived to be closest to the ideal. This result

Table 3 Factors isolated by Varimax rotation

\begin{tabular}{|c|c|c|c|}
\hline Factor & $\begin{array}{l}\text { Factor } \\
\text { loadings }\end{array}$ & $\begin{array}{l}\text { Consultancy } \\
\text { closest }\end{array}$ & Significance \\
\hline \multicolumn{4}{|l|}{ Professional competency: } \\
\hline $\begin{array}{l}\text { stable, consistent image } \\
\text { good knowledge of }\end{array}$ & 0,662 & $\mathbf{F}$ & 2,16 \\
\hline training & 0,762 & $\mathbf{A}$ & $2,50^{\mathrm{a}}$ \\
\hline professional & 0,87 & $\mathrm{~F} / \mathrm{C}$. & $2,09^{\mathrm{a}}$ \\
\hline good quality programs & 0,821 & $\mathbf{F}$ & $2,09^{\mathrm{a}}$ \\
\hline \multicolumn{4}{|l|}{ Service competency: } \\
\hline service oriented & 0,625 & $\mathbf{E}$ & 5,35 \\
\hline $\begin{array}{l}\text { good identification of } \\
\text { client needs }\end{array}$ & 0,725 & $\mathrm{E}$ & $4,88^{\mathrm{a}}$ \\
\hline analyse problems & 0,691 & $\mathbf{E}$ & $4,70^{\mathrm{a}}$ \\
\hline $\begin{array}{l}\text { customize programs to } \\
\text { client needs }\end{array}$ & 0,708 & $\mathbf{E}$ & $3,83^{\mathrm{a}}$ \\
\hline \multicolumn{4}{|l|}{ Potency: } \\
\hline large organization & 0,742 & B & 2,95 \\
\hline wide range of services & 0,74 & $\mathrm{~B} / \mathrm{E}$ & $3,17 / 3,19$ \\
\hline \multicolumn{4}{|l|}{ Supportiveness: } \\
\hline medium priced & 0,58 & $\mathbf{E}$ & 3,87 \\
\hline soft-sell & 0,56 & $\mathbf{E}$ & 3,05 \\
\hline South African based: & & B & 5,06 \\
\hline Use on a continuing basis: & & G & 5,11 \\
\hline $\begin{array}{l}\text { Programs are consultant } \\
\text { independent }\end{array}$ & & $\mathbf{G}$ & 2,79 \\
\hline Innovative and progressive: & & G & $3,17^{\mathrm{a}}$ \\
\hline $\begin{array}{l}\text { Both Individual/skills and } \\
\text { management/organiza- } \\
\text { tional development: }\end{array}$ & & $\begin{array}{l}\text { All except } \\
C \text { and } G\end{array}$ & (N.S.D.) \\
\hline
\end{tabular}

"Indicates a significant difference at the $5 \%$ level. therefore confirms the primary hypothesis, and the null hypothesis is rejected. These quantitative results are further confirmed by the large number of critical subjective comments provided, relating to the lack of particularly service competence factors by consultancies.

\section{Marketing orientation}

The variables that relate to the marketing of consultancy services were extracted in order to test the secondary hypothesis, namely that the means of the ideal consultancy for the marketing variable will differ from the means of other consultancies. These results are summarized in Tables 4(a) and (b) below.

These tables indicate that training and development consultancies differ significantly in their image from the perceived ideal in relation to the marketing aspect of their services. The exception is consultancy $\mathrm{E}$ which shows an opposite trend from other consultancies in this respect, in that they are perceived to be closer to the ideal consultancy on these variables. These quantitative conclusions are once again confirmed by the subjective comments. The null hypothesis is therefore rejected for this secondary hypothesis, and the alternative hypothesis, $H_{1}$ is accepted.

Comparison of images in companies of different size The two employment groups to be compared were separated and the means for the ideal consultancy and all consultancies were calculated. The hypothesis in this instance states that the means of the ideal consultancy and all consultancies will not differ in companies of different size. The null hypothesis should therefore be accepted. The results for the two employment groups show that at the $95 \%$ confidence level, no significant differences exist between the perceptions of the two employment groups when the $t$ test was applied to the means.

\section{Summary of findings}

Significant differences were found to exist between the ideal consultancy and the other consultancies as perceived by the respondents. This was evident for most consultancies except for consultancy $\mathrm{E}$ which had the largest number of instances where no significant differences were found. Factor analysis tended to substantiate these findings, as six out of eight differences were found on the competency factors, which can be regarded as representing the efficacy of consultants. These findings were further substantiated by the subjective comments made.

Table 4a Differences between means of ideal and consultancies on marketing variables

\begin{tabular}{ccccccccccc}
\hline Variable & $\begin{array}{c}\text { Mean } \\
\text { ideal }\end{array}$ & $\begin{array}{c}\text { Mean } \\
\text { All/I }\end{array}$ & $\begin{array}{c}\text { Mean } \\
\text { A/I }\end{array}$ & $\begin{array}{c}\text { Mean } \\
\text { B/I }\end{array}$ & $\begin{array}{c}\text { Mean } \\
\text { C/I }\end{array}$ & $\begin{array}{c}\text { Mean } \\
\text { D/I }\end{array}$ & $\begin{array}{c}\text { Mean } \\
\text { E/I }\end{array}$ & $\begin{array}{c}\text { Mean } \\
\text { F/I }\end{array}$ & $\begin{array}{c}\text { Mean } \\
\text { G/I }\end{array}$ & $\begin{array}{c}\text { Mean } \\
\text { H/I }\end{array}$ \\
\hline 2 & 4,6 & $2,86^{\mathrm{a}}$ & $3,00^{\mathrm{a}}$ & $2,37^{\mathrm{a}}$ & $2,34^{\mathrm{a}}$ & $2,42^{\mathrm{a}}$ & 5,35 & $2,43^{\mathrm{a}}$ & $2,15^{\mathrm{a}}$ & $2,33^{\mathrm{a}}$ \\
3 & 6,4 & $4,19^{\mathrm{a}}$ & $4,25^{\mathrm{a}}$ & $4,13^{\mathrm{a}}$ & $4,19^{\mathrm{a}}$ & $4,55^{\mathrm{a}}$ & 4,29 & $3,69^{\mathrm{a}}$ & $4,54^{\mathrm{a}}$ & $4,11^{\mathrm{a}}$ \\
5 & 6,3 & $4,47^{\mathrm{a}}$ & $4,29^{\mathrm{a}}$ & $4,72^{\mathrm{a}}$ & $4,34^{\mathrm{a}}$ & $4,39^{\mathrm{a}}$ & $4,88^{\mathrm{a}}$ & $4,34^{\mathrm{a}}$ & $2,29^{\mathrm{a}}$ & $4,46^{\mathrm{a}}$ \\
8 & 4,2 & $5,36^{\mathrm{a}}$ & $5,23^{\mathrm{a}}$ & $5,49^{\mathrm{a}}$ & $5,64^{\mathrm{a}}$ & $5,28^{\mathrm{a}}$ & 3,87 & $6,07^{\mathrm{a}}$ & $5,87^{\mathrm{a}}$ & $5,58^{\mathrm{a}}$ \\
10 & 4,9 & $4,19^{\mathrm{a}}$ & 4,15 & 4,24 & 4,41 & $3,90^{\mathrm{a}}$ & 4,10 & $3,87^{\mathrm{a}}$ & 4,67 & 4,31 \\
13 & 1,5 & $2,29^{\mathrm{a}}$ & $3,42^{\mathrm{a}}$ & $2,71^{\mathrm{a}}$ & $4,26^{\mathrm{a}}$ & $3,33^{\mathrm{a}}$ & 1,81 & $2,93^{\mathrm{a}}$ & $4,31^{\mathrm{a}}$ & $4,68^{\mathrm{a}}$ \\
14 & 5,6 & $3,53^{\mathrm{a}}$ & $3,24^{\mathrm{a}}$ & $4,11^{\mathrm{a}}$ & $3,06^{\mathrm{a}}$ & $3,16^{\mathrm{a}}$ & $4,70^{\mathrm{a}}$ & $3,26^{\mathrm{a}}$ & $3,00^{\mathrm{a}}$ & $3,33^{\mathrm{a}}$ \\
16 & 3,1 & 3,74 & 3,41 & 3,66 & 3,66 & $4,23^{\mathrm{a}}$ & 3,05 & 3,66 & $4,62^{\mathrm{a}}$ & $4,05^{\mathrm{a}}$ \\
20 & 4,8 & 4,13 & 4,06 & 4,24 & 3,84 & $3,95^{\mathrm{a}}$ & 4,11 & $3,95^{\mathrm{a}}$ & 5,11 & $3,71^{\mathrm{a}}$ \\
25 & 3,1 & $4,05^{\mathrm{a}}$ & $4,19^{\mathrm{a}}$ & $4,33^{\mathrm{a}}$ & $4,79^{\mathrm{a}}$ & 3,48 & 3,76 & $4,95^{\mathrm{a}}$ & 2,79 & 3,24 \\
27 & 1,2 & $3,00^{\mathrm{a}}$ & $2,94^{\mathrm{a}}$ & $2,69^{\mathrm{a}}$ & $3,81^{\mathrm{a}}$ & $3,26^{\mathrm{a}}$ & $2,74^{\mathrm{a}}$ & $2,55^{\mathrm{a}}$ & $3,04^{\mathrm{a}}$ & $3,60^{\mathrm{a}}$ \\
28 & 5,8 & $2,90^{\mathrm{a}}$ & $2,97^{\mathrm{a}}$ & $3,28^{\mathrm{a}}$ & $2,27^{\mathrm{a}}$ & $2,92^{\mathrm{a}}$ & $3,83^{\mathrm{a}}$ & $2,50^{\mathrm{a}}$ & $2,22^{\mathrm{a}}$ & $3,06^{\mathrm{a}}$ \\
\hline
\end{tabular}

Indicates a significant difference at the $5 \%$ level. 
Table 4b Number of significant differences for each consultancy

\begin{tabular}{ccc} 
Consultancy & $\begin{array}{c}\text { No significant } \\
\text { difference }\end{array}$ & $\begin{array}{c}\text { Significant } \\
\text { difference }\end{array}$ \\
\hline A & 3 & 9 \\
B & 3 & 9 \\
C & 3 & 9 \\
D & 1 & 11 \\
E & 8 & 4 \\
F & 1 & 11 \\
G & 3 & 9 \\
H & 3 & 9 \\
Mean all & 2 & 10 \\
\hline
\end{tabular}

A general lack of a marketing orientation was proved by extracting the marketing variables and comparing the means for these variables with those for the ideal. The exception proved to be consultancy $\mathrm{E}$ which exhibited significant differences from the ideal on only four variables. Although the sample sizes were relatively small and the response rates rather low for the ideal, no significant differences were found to exist in the perceived images of the ideal and other consultancies in the two employment groups. It was therefore concluded that perceptions did not differ according to the size of the company.

All these results are subject to the limitations of the errors of the methodology and should be seen in the light of the constraints of a pilot study.

\section{Conclusions and recommendations}

The conclusions that can be drawn from the results of this pilot study indicate that the image of training and development consultancy in general does not correspond with the ideal as perceived by their clients. Such client-oriented service factors as correct analysis of problems, identification of needs and customizing programmes to the specific requirements of the client companies were seen to be lacking. This view was held by organizations of all sizes in the PWV area.

Certain consultancies were perceived as closely approximating some of the desired image attributes of the ideal consultancy by giving attention to specific client needs. These consultancies must therefore be regarded as making a contribution to the alleviation of the critical high-level manpower shortage as described. However, there appears to be an urgent need for more professionalism in the form of competence and service among existing consultancies, and a need for more consultancies to make a significant impact on the manpower shortage.

It is recognized that training and development consultancies currently operate within certain constraints. One of these constraints is the lack of recognition of their professional status. Coetzee (1980), in generalizing about this lack of recognition in personnel consultancies, described the disadvantage of operation from a base of 'unprofessionalism' as an aspect which deserved urgent attention if the needs for optimal manpower development and utilization in South Africa were to be satisfied.

It has been stated that management development in developing countries must meet the development goals and ethos of that country. The criteria of relevance, flexibility and national identity, among others, should be met for management development to be effective. 'Developing countries can ill-afford the luxury of accepting irrelevant fashions in management education' (Bharadwaj, 1975:152). Another of the constraints which training and development consultancies are subjected to, is that it may not yet be feasible to meet the above criteria and remain viable and profitable operations. This is due to factors such as the relatively small size of the potential market, the limited scope and time for the pertinent research and development, and the shortage of suitably qualified and experienced training consultants. Coupled with these factors are the consultancies' own internal lack of management resources, reflecting a 'Catch 22' situation.

In view of these conclusions, the following recommendations are made:

(i) Training and development practitioners need improved standards and recognition as a profession in order to upgrade the credibility and importance of this function. With this will come the increased professionalism of the consultancy service in this area.

(ii) In order to improve their efficacy, training and development consultancies need to improve and broaden the management expertise of their consultants. This would broaden their perspectives of organizations and their problems, and improve their ability to identify with the problems of management. This would lead to greater credibility of this service with client companies. This is recognized as constituting a longterm objective for some consultancies.

(iii) The legislative structure currently lends itself to abuse by some consultants. The shortage of manpower in the Department of Manpower is acknowledged; however, a revision of the current structure appears necessary if this essential service of high-level manpower development is to be improved rapidly and effectively.

As this research represented a limited pilot study into the current image of training and development consultancy in South Africa, some further areas suggested for research are: (i) An investigation into the smaller consultancies not covered by this research.

(ii) A comparative study of the images held by organizations in different sectors such as for example, the manufacturing sector, the financial sector, and the retail sectors.

(iii) There may be differences in perceptions in different geographic regions, and a comparative study of this nature may reveal interesting results.

(iv) Comparisons between the images of training and development consultancies found in public sector organizations as compared to those found in the private sector. Cultural differences in the traditionally conservative public sector may well result in different perceptions.

\section{References}

Argyris, C. 1970. Intervention Theory And Method: A Behavioural Sciences View. Reading: Addison-Wesley.

Bannister, D. \& Fransella, F. 1980. Inquiring Man. 2nd Edition. Middlesex: Penguin.

Bharadwaj, S.B.L. 1975. Management Development in the Developing Countries. In Taylor, B. and Lippitt, G. (Eds.) Management Development And Training Handbook. London: McGraw-Hill.

Blake, R. \& Mouton, J.S. 1976. Consultation. Reading: Addison-Wesley.

Braude, J.H. 1975. The Image of Private Hospital Services in Johannesburg. Johannesburg: University of the Witwatersrand. (Unpublished MBA Dissertation.)

Coetzee, J. 1980. Die Rol en Plek van die Personeelkonsultant met Betrekking tot die Aanwending van Menslike Hulpbronne in die 80's. People and Profits, vol.8(5).

Cogill, C.J. 1981. Managerial Role Perception in Organizations. Johannesburg: University of the Witwatersrand. (Unpublished $\mathrm{PhD}$ thesis.) 
Gabler, R.L. 1982. Manpower Training Centres and Schemes. Cape Town: University of Cape Town. (Unpublished MBA Technical Report.)

Gallessich, J. 1982. The Profession and Practise of Consultation. San Francisco: Jossey - Bass.

Gerdes, L.C., Osche, R., Stander, C., van Ede, D., (in collaboration with Meyer, W.F.). 1981. The Developing Adult. Durban: Butterworth.

Harbison, F.H. 1973. Human Resources as the Wealth of Nations, London: Oxford University Press.

Hendricks, D.E. 1981. A Preliminary Survey of the Training Needs of Trainers and Available Training. Cape Town: University of Cape Town . (Unpublished Technical Report for Advanced Diploma in Business Administration.)

Kolb, D.A. \& Frohman, A.L. 1970. Organisational Development Approach to Consultation. Sloan Manage. Rev., vol.12, (1), Fall, $51-65$.

Lippitt, G.L. 1981. Criteria for Selecting, Evaluating and Developing Consultants. Training Develop. J., June, 24-38.

Lippitt, G.L. \& Lippitt, R. 1978. The Consultation Process In Action. La Jolla: University Association Inc.

Matthews, I. 1972. Management Consultancy in South Africa. Cape Town: University of Cape Town. (Unpublished MBA Technical Report.)

McLagan, P.A. 1983. Models For Excellence: The Conclusions and Recommendations of the ASTD Training and Development Competency Study. Washington: American Society for Training and Development.
Mumford, A. 1975. The Role of the External Consultant. In Taylor, B. and Lippitt, G. (Eds). Management Training and Development Handbook. New York: McGraw-Hill.

Polkinghorne, E.R. 1976. The Image of Supermarkets and Housebrands. Johannesburg: University of the Witwatersrand. (Unpublished MBA Research Report.)

Polovin, G.A. 1975. Businessmen's Perceptions of the Image of South African Banks. Johannesburg: University of the Witwatersrand. (Unpublished MBA Research Report.)

Ries, A.L. \& Traut, J. 1981. Positioning: The Battle For Your Mind. New York: McGraw-Hill.

Sadie, J.L. 1978. Population and Society. People And Profits, November.

Sadie, J.L. 1979. The Socio-political Requirements for Stability and Growth in Southern Africa. J. Studies Econ. Econometrics. Stellenbosch: University of Stellenbosch, Bureau for Economic Research. (Report no. 6.)

Schein, E. 1969. Process Consultation. Reading: Addison-Wesley.

Schein, E. \& Hall, D.H. 1967. The Student Image of the Teacher. J. Appl. Behav. Sci., (3), 305-337.

South Africa. 1981. Manpower Training Act, Act 56 of 1981 As Amended. Pretoria: Government Printers.

South Africa, 1980. White Paper on the Report of the National Manpower Commission on High-level Manpower in South Africa. Pretoria: Government Printers. (Report no. WPJ 1981.)

Trump, L. 1983. Training Consultancies: Using them Wisely. Management, October, $91-101$. 